\title{
EVALUATION OF ADIPOKINE CHEMERIN IN HYPERTENSIVE OBESE
}

\author{
AVALIAÇÃO DA ADIPOCINA CHEMERIN EM OBESOS HIPERTENSOS
}

\author{
Dalia Ramzy IBRAHIM ${ }^{1}$; Mervat Elsayed TAHA ${ }^{1}$; Amaal Mohamed KAMAL ${ }^{1}$ \\ Biological Applications Department, Nuclear Research Center, Atomic Energy Authority, Cairo, Egypt. \\ dr.dalia_ramzy@yahoo.com
}

\begin{abstract}
Chemerin is an adipokine secreted by adiopose tissue and has a role in obesity and hypertension. This study aims at assessing the level of the adipokine chemerin in obesity and/or hypertension and correlating its level with the inflammatory marker hs-CRP and predictors of atherosclerosis as lipid profile, insulin resistance, systolic (SBP) and diastolic blood pressure (DBP).Volunteers were divided into 4 equal groups according to body mass index (BMI) and blood pressure: normal weight group (BMI $\leq 24.9 \mathrm{~kg} / \mathrm{m}^{2}$ ), overweight group $\left(B M I=25.0-29.9 \mathrm{~kg} / \mathrm{m}^{2}\right)$, normotensive obese group $\left(B M I \geq 30.0 \mathrm{~kg} / \mathrm{m}^{2}\right)$ and hypertensive obese group (BMI $\geq 30.0 \mathrm{~kg} / \mathrm{m}^{2}$ ). Chemerin, high-sensitivity C-reactive protein (hs-CRP), lipid profile, fasting blood glucose (FBG) and fasting insulin (FI) were evaluated in the mentioned groups. The results showed that there were significant increases of chemerin, hs-CRP, low density lipoprotein (LDL), SBP and DBP in hypertensive obese group compared to normotensive obese, overweight and normal weight groups. Moreover the only significant positive correlation between chemerin and hs-CRP was observed in the obese hypertensive group. The normotensive obese group showed significant increases of hs-CRP, LDL, triglyceride (TG), FBG, FI and the homeostasis model assessment-insulin resistance index (HOMA-IR) compared to the overweight and normal weight groups. Regarding the overweight group, there were significant increases in chemerin, hs-CRP, cholesterol, LDL, TG compared to the normal weight group, while the HDL levels were significantly lower compared to the two obese groups. These results revealed that the pro-inflammatory adipokine chemerin increases in obesity associated with hypertension, leading to the suggestion that there is a definite dysregulation of the pro-inflammatory and anti-inflammatory parameters towards the pro-inflammatory when hypertension and obesity are associated.
\end{abstract}

KEYWORDS: Essential hypertension. Cytokines. Pro-inflammation. Obesity.

\section{INTRODUCTION}

Adipose tissue is a metabolically active organ, as it secretes various adipokines and cytokines (RONDINONE, 2006). Excess white adipose tissue (WAT) in obesity is characterized by dysregulation of pro-inflammatory and antiinflammatory adipokines. This disequilibrium can induce a chronic inflammatory state and act as a pathogenic link between obesity and many diseases such as type 2 diabetes mellitus, dyslipidemia, hypertension and coronary heart disease (BULLO et al., 2007; MAURY; BRICHARD, 2010; FERNANDEZ-SANCHEZ et al., 2011).

Chemerin is one of the pro-inflammatory adipokines that is secreted in an inactive form as prochemerin and then activated through proteolytic cleavage (WANG; NAKAYAMA, 2010). Chemerin regulates adipogenesis, glucose metabolism and inflammation, it also recruits and activates immune cells (JOHN et al., 2007; ROURKE et al., 2013). Chemerin is an important factor in the development and progression of atherosclerosis; it promotes adhesion of macrophages to vascular cell adhesion molecule-1 (VCAM-1) and fibronectin (OUCHI et al., 2011). The accumulation of chemerin in an atherosclerotic lesion attracts immune cells which leads to remodeling of the vessel wall and inducing a direct inflammatory effect on vascular endothelial cells (YAMAWAKI, 2011). Furthermore, the serum level of chemerin was associated with aortic stiffness in healthy individuals (HOO et al., 2012).

Hypertension is a health problem that may predispose to ischemic heart disease and affects target organs including the heart, kidneys and eyes (KANNEL, 1996). Many authors suggested the role of chemerin on hypertension and obesity. Chemerin plays a role in obesity, diabetes and atherosclerosis which are important risk factors in essential hypertension. Chemerin is an endogenous vasoconstrictor that is produced by visceral and perivascular adipose tissue (WATTS et al., 2013). In addition, the levels of chemerin correlated with obesity factors such as BMI and triglyceride levels (BOZAOGLU et al., 2007; BA et al., 2019). On the other hand, HART AND GREAVES (2010) reported that serum chemerin levels are elevated in obese, insulin-resistant, and inflammatory states. Its 
Evaluation of Adipokine...

level was significantly positively associated with the inflammatory marker hs-CRP (GU et al., 2015).

The aim of the present work was to assess the level of chemerin in obesity and/ or hypertension in Egyptian individuals and to correlate its level with the marker of inflammation, CRP, and some predictors of atherosclerosis as lipid profile, insulin resistance, systolic and diastolic blood pressure.

\section{MATERIAL AND METHODS}

\section{Patients}

This study was performed on 80 individuals, 39 males and 41 females, age ranged from 40 to 50 years. They were divided according to the BMI and blood pressure into 4 equal groups: normal weight group, 12 males and 8 females, (BMI $\left.\leq 24.9 \mathrm{~kg} / \mathrm{m}^{2}\right)$, overweight group, 10 males and 10 females, $\left(\right.$ BMI $\left.=25.0-29.9 \mathrm{~kg} / \mathrm{m}^{2}\right)$, normotensive obese group, 8 males and 12 females, (BMI $\geq 30.0$ $\mathrm{kg} / \mathrm{m}^{2}$ ) and hypertensive obese group, 9 males and 11 females, (BMI $\left.\geq 30.0 \mathrm{~kg} / \mathrm{m}^{2}\right)$. Hypertension was defined as systolic BP (SBP) $\geq 140 \mathrm{mmHg}$ or diastolic BP (DBP) $\geq 90 \mathrm{mmHg}$ and/or using antihypertensive drug therapy (CHOBANIAN et al., 2003). Clinical and laboratory examinations were performed to exclude secondary hypertension, chronic heart failure, valvular heart disease, cardiomyopathy, atrial fibrillation, diabetes mellitus, renal or hepatic dysfunction, cancer, systemic inflammatory diseases, chronic or acute infectious diseases and auto-immune diseases. The laboratory tests included creatinine, aspartate aminotransferase (AST), albumin, the erythrocyte sedimentation rate (ESR) and glycated hemoglobin (HBAlc). Demographic charachteristics as age, sex, smoking habits (all studied individuals were non-smokers) and antihypertensive drug use were noted. Body mass index (BMI) was calculated as weight $(\mathrm{Kg})$ divided by height squared $\left(\mathrm{m}^{2}\right)$.

\section{Collection of blood samples and biochemical analysis}

After the patients'consent, blood samples were taken in the morning after $30 \mathrm{~min}$. rest following 12-14 $\mathrm{h}$. fasting period. Samples were centrifuged at $3000 \mathrm{rpm}$ for $10 \mathrm{~min}$. and the sera for insulin and chemerin analysis were stored at $-80^{\circ} \mathrm{C}$. Fasting serum glucose, total cholesterol, HDLcholesterol, LDL-cholesterol and triglyceride (TG) concentrations were evaluated immediately by enzymatic colorimetric methods. The quantitative determination of high sensitive C-reactive protein (hs-CRP) was determined in serum by immuno-
IBRAHIM, D. R.; TAHA, M. E.; KAMAL, A. M.

turbidimetric assay using Roche Diagnostics $\mathrm{GmbH}$ (Mannheim, Germany). The concentration of insulin was measured by immunoradiometric assay kit, DIA source INS-IRMA kit, supplied by DIA source ImmunoAssays S.A. (Belgium). Chemerin levels were measured in blood sera using a commercially available enzyme-linked immunosorbent assay (ELISA) kit supplied by R\&D systems (Minneapolis, MN 55413, USA). The homeostasis model assessment-insulin resistance index (HOMAIR) was calculated by the equation: HOMA-IR = Fasting glucose $(\mathrm{mg} / \mathrm{dl}) \times$ Fasting insulin $(\mu \mathrm{U} / \mathrm{ml}) \div$ 405. The cutoff point to define insulin resistance corresponds to HOMA-IR $\geq 3.8$ (SHIRAI, 2004). Body mass index (BMI) was calculated as weight $(\mathrm{Kg})$ divided by the square of height $(\mathrm{m})$.

\section{Compliance and ethical standards}

All procedures performed involving human participants were in accordance with the ethical standards of the institutional and national research committee and with the 1964 Helsinki declaration and its later amendments or comparable ethical standards. The authors declare no conflicts of interest. Informed consent was obtained from all individual participants included in the study.

\section{Statistical analysis}

Data were analyzed using the statistical package for social sciences (SPSS, version 20 for windows, Chicago, USA). Results were expressed as means \pm standard error (SE). Normality of the distribution of the data was determined using a Kolmogorov-Smirnov test. Statistical differences between the groups were performed using one-way analysis of variance (ANOVA) test. $\mathrm{P}<0.05$ was considered statistically significant. Correlation analysis between serum chemerin levels and the studied variables was performed by Pearson correlation test.

\section{RESULTS}

Table 1 summarizes the data of age, BMI, SBP and DBP in the 4 tested groups (normal weight, overweight, normotensive obese and hypertensive obese). To clarify the effect of obesity, the percentage of change 1 was calculated between each of the overweight and normotensive obese group, and the normal weight group, while to evaluate the effect of hypertension, the percentage of change 2 was analyzed between the hypertensive and the normotensive obese groups. Insignificant changes were observed regarding SBP and DBP in the normal, overweight and normotensive obese groups. 
The SBP and DBP significantly increased in hypertensive obese group compared to the normotensive obese and the percentage of change between them was $18 \%$ and $13 \%$ respectively.

Table 1. Clinical features of the studied groups

\begin{tabular}{|c|c|c|c|c|c|}
\hline Parameters & $\begin{array}{l}\text { Normal } \\
\text { Weight }\end{array}$ & Over Weight & $\begin{array}{c}\text { Normotensive } \\
\text { Obese }\end{array}$ & Hypertensive Obese & $P$ value \\
\hline $\begin{array}{c}\text { Age (yrs) } \\
\% \text { of change } 1 \\
\% \text { of change } 2\end{array}$ & $45.00 \pm 2.22^{\mathrm{a}}$ & $\begin{array}{c}44.81 \pm 1.89^{\mathrm{a}} \\
-0.40\end{array}$ & $\begin{array}{c}45.90 .72 \pm 2.05^{\mathrm{a}} \\
2.0\end{array}$ & $\begin{array}{c}48.272 \pm 1.76^{\mathrm{a}} \\
- \\
5.14\end{array}$ & 0.597 \\
\hline $\begin{array}{l}\text { BMI }\left(\mathrm{Kg} / \mathrm{m}^{2}\right) \\
\% \text { of change } 1 \\
\% \text { of change } 2\end{array}$ & $23.51 \pm 0.47^{\mathrm{d}}$ & $\begin{array}{c}28.24 \pm 0.21^{\mathrm{c}} \\
20.09\end{array}$ & $\begin{array}{c}34.20 \pm 1.16^{\mathrm{b}} \\
45.45\end{array}$ & $\begin{array}{c}37.40 \pm 0.90^{\mathrm{a}} \\
- \\
9.32\end{array}$ & 0.001 \\
\hline $\begin{array}{c}\text { SBP }(\mathrm{mm} \\
\mathrm{Hg}) \\
\% \text { of change1 } \\
\% \text { of change2 }\end{array}$ & $117.36 \pm 3.21^{\mathrm{b}}$ & $\begin{array}{c}125.72 \pm 3.28^{b} \\
7.12\end{array}$ & $\begin{array}{c}120.36 \pm 2.79^{b} \\
2.02\end{array}$ & $\begin{array}{c}142.45 \pm 5.20^{\mathrm{a}} \\
- \\
18\end{array}$ & 0.000 \\
\hline $\begin{array}{c}\text { DBP }(\mathrm{mm} \\
\mathrm{Hg}) \\
\% \text { of change } 1 \\
\% \text { of change } 2\end{array}$ & $76.45 \pm 1.81^{\mathrm{b}}$ & $\begin{array}{c}81.36 \pm 2.34^{\mathrm{ab}} \\
6\end{array}$ & $\begin{array}{c}76.54 \pm 1.74^{\mathrm{b}} \\
0.1\end{array}$ & $\begin{array}{c}86.63 \pm 3.74^{\mathrm{a}} \\
- \\
13\end{array}$ & 0.021 \\
\hline
\end{tabular}

Values are expressed as means \pm SE. Same superscript in the same row means no significant difference; Different superscripts in the same raw $(\mathrm{a}, \mathrm{b}, \mathrm{c})$ means significant differences $(\mathrm{p}<0.05) ; \%$ of change 1 : between each of the overweight and normotensive obese group, and the normal weight group (It clarifies the effect of obesity); \% of change 2: between the hypertensive obese group and the normotensive obese group (It clarifies the effect of hypertension)

The analysis of biochemical parameters in Table 2 reveals that there were significant increases in chemerin, hs-CRP and LDL in the hypertensive obese group compared to the other three groups. The obese hypertensives showed also significant increases in FBG, FI and HOMA-IR compared to the normal and overweight groups, and insignificant change with the normotensive obese one. The normal and overweight groups, on the other hand, showed insignificant changes in FBG, FI and HOMA-IR. However, cholesterol showed insignificant differences between hypertensive obese, normotensive obese and overweight. There was significant increase in HDL in the normal group compared to the overweight and both obese groups. Meanwhile, there was insignificant difference between the normotensive and hypertensive groups with obesity.

Table 2. Biochemical features of the studied groups

\begin{tabular}{cccccc}
\hline Parameters & $\begin{array}{c}\text { Normal } \\
\text { Weight }\end{array}$ & Over Weight & $\begin{array}{c}\text { Normotensive } \\
\text { Obese }\end{array}$ & $\begin{array}{c}\text { Hypertensive } \\
\text { Obese }\end{array}$ & P value \\
\hline $\begin{array}{c}\text { Hs-CRP(mg/L) } \\
\text { \% of change1 }\end{array}$ & $3.56 \pm 0.51^{\mathrm{d}}$ & $\begin{array}{c}8.21 \pm 0.64^{\mathrm{c}} \\
130.6\end{array}$ & $\begin{array}{c}13.64 \pm 1.39^{\mathrm{b}} \\
282.9\end{array}$ & $23.12 \pm 0.55^{\mathrm{a}}$ & 0.000 \\
\%of change2 & & & & 69.4 & \\
& & & & & \\
Cholesterol(mg/dl) & $156.53 \pm 5.21^{\mathrm{b}}$ & $219.64 \pm 11.39^{\mathrm{a}}$ & $230.945 \pm 6.78^{\mathrm{a}}$ & $255.345 \pm 19.92^{\mathrm{a}}$ & 0.000 \\
\% of change1 & & 40.3 & 47.5 & - & 10.5 \\
\% of change 2 & & & & $155.49 \pm 4.93^{\mathrm{a}}$ & 0.000 \\
LDL(mg/dl) & $110.77 \pm 2.39^{\mathrm{d}}$ & $132.65 \pm 2.71^{\mathrm{c}}$ & $145.10 \pm 2.57^{\mathrm{b}}$ & - &
\end{tabular}




\begin{tabular}{|c|c|c|c|c|c|}
\hline $\begin{array}{l}\text { HDL }(\mathrm{mg} / \mathrm{dl}) \\
\% \text { of change } 1 \\
\% \text { of change } 2\end{array}$ & $41.20 \pm 1.07^{\mathrm{a}}$ & $\begin{array}{c}36.78 \pm 0.54^{\mathrm{b}} \\
-10.7\end{array}$ & $\begin{array}{c}32.17 \pm 0.80^{c} \\
-21.9\end{array}$ & $\begin{array}{c}33.93 \pm 0.96^{\mathrm{c}} \\
- \\
5.4\end{array}$ & 0.000 \\
\hline $\begin{array}{l}\text { TG(mg/dl) } \\
\% \text { of change1 } \\
\% \text { of change } 2\end{array}$ & $120.36 \pm 2.93^{c}$ & $\begin{array}{c}222.23 \pm 21.23^{b} \\
84.6\end{array}$ & $\begin{array}{c}274.500 \pm 3.89^{\mathrm{a}} \\
128.0\end{array}$ & $\begin{array}{c}286.272 \pm 2.30^{\mathrm{a}} \\
- \\
4.2\end{array}$ & 0.000 \\
\hline $\begin{array}{l}\text { FBG }(\mathrm{mg} / \mathrm{dl}) \\
\% \text { of change } 1\end{array}$ & $88.75 \pm 2.89^{b}$ & $\begin{array}{c}91.16 \pm 1.82^{b} \\
2.7\end{array}$ & $\begin{array}{c}120.09 \pm 10.98^{\mathrm{a}} \\
35.3\end{array}$ & $\begin{array}{c}123.22 \pm 10.67^{\mathrm{a}} \\
- \\
2.6\end{array}$ & 0.003 \\
\hline $\begin{array}{l}\text { Insulin }(\mu \mathrm{IU} / \mathrm{ml}) \\
\% \text { of change } 1 \\
\% \text { of change } 2\end{array}$ & $5.29 \pm 0.52^{b}$ & $\begin{array}{c}8.12 \pm 0.15^{b} \\
53.6\end{array}$ & $\begin{array}{c}14.08 \pm 2.01^{\mathrm{a}} \\
166.1\end{array}$ & $\begin{array}{c}14.88 \pm 2.33^{\mathrm{a}} \\
- \\
5.6\end{array}$ & 0.000 \\
\hline $\begin{array}{l}\text { HOMA-IR } \\
\% \text { of change1 } \\
\% \text { of change } 2\end{array}$ & $1.38 \pm 0.16^{\mathrm{b}}$ & $\begin{array}{c}1.80 \pm 0.07^{\mathrm{b}} \\
30.9\end{array}$ & $\begin{array}{c}4.93 \pm 0.73^{\mathrm{a}} \\
257.4\end{array}$ & $\begin{array}{c}5.13 \pm 0.52^{\mathrm{a}} \\
- \\
4.0\end{array}$ & 0.000 \\
\hline $\begin{array}{l}\text { Chemerin }(\mathrm{ng} / \mathrm{ml}) \\
\% \text { of change } 1 \\
\% \text { of change } 2\end{array}$ & $41.38 \pm 2.68^{c}$ & $\begin{array}{c}108.62 \pm 14.69^{b} \\
162.5\end{array}$ & $\begin{array}{c}110.97 \pm 29.59^{b} \\
168.1\end{array}$ & $\begin{array}{c}414.31 \pm 58.24^{\mathrm{a}} \\
- \\
273.3\end{array}$ & 0.000 \\
\hline
\end{tabular}

Values are expressed as means \pm SE. Same superscript in the same row means no significant difference; Different superscripts in the same raw ( $a, b, c)$ means significant differences ( $<<0.05) ; \%$ of change1: between each of the overweight and normotensive obese group, and the normal weight group (It clarifies the effect of obesity); \% of change 2 : between the hypertensive obese group and the normotensive obese group (It clarifies the effect of hypertension)

Although hs-CRP showed significant differences between the four groups, the percentage of changes clarify these differences as they reached $130 \%$ and $283 \%$ in overweight and normotensive obese compared to normal, pointing to the role of obesity. Moreover, hypertension plays a role also in increasing the level of hs-CRP as the obese hypertensives experienced the highest level and the percentage of change between normotensive and hypertensive obese was $69 \%$. Chemerin simulates, to a great extent, the trend of increase of hs-CRP i.e. significant increase of this adipokine in overweight and normotensive obese where the percentage of change reached $162 \%$ and $168 \%$ in the previous two groups respectively compared to normal. The highest significant increase of chemerin was observed in hypertensive obese, where the percentage of change reached up to $273 \%$ compared to normotensive obese.

Collectively, it could be stated that hypertension caused significant increases in SBP, DBP, hs-CRP, chemerin and LDL as shown in hypertensive obese group compared to normotensive obese. On the other hand, obesity caused significant increases in hs-CRP, chemerin,
LDL, TG and a significant decrease in HDL in normotensive obese individuals compared to normal. FBG, FI and HOMA-IR experienced insignificant differences between normal and overweight, and significant increase in normotensive and hypertensive obese.

Table 3 illustrates the correlation between serum chemerin and all tested parameters in normal, overweight, normotensive obese and hypertensive obese subjects. In normal, there was a negative significant correlation between chemerin and diastolic blood pressure, and a positive significant correlation with fasting glucose and HOMA. In overweight, there was a negative significant correlation with SBP and a positive significant correlation with FI. In obese hypertensive group, there was a positive significant correlation between chemerin and hs-CRP. 
Table 3. Correlations of chemerin with clinical and metabolic parameters

\begin{tabular}{ccccccccc}
\hline Parameters & \multicolumn{2}{c}{$\begin{array}{c}\text { Serum chemerin in } \\
\text { normal weight }\end{array}$} & \multicolumn{2}{c}{$\begin{array}{c}\text { Serum chemerin in } \\
\text { overweight }\end{array}$} & \multicolumn{2}{c}{$\begin{array}{c}\text { Serum chemerin } \\
\text { in normotensive } \\
\text { obese }\end{array}$} & \multicolumn{2}{c}{$\begin{array}{c}\text { Serum chemerin } \\
\text { in hypertensive } \\
\text { obese }\end{array}$} \\
& R value & P value & R value & P value & Rvalue & P value & R value & P value \\
Age & 0.197 & 0.562 & -0.161 & 0.636 & 0.226 & 0.505 & 0.197 & 0.561 \\
BMI & 0.342 & 0.303 & 0.433 & 0.183 & -0.165 & 0.623 & 0.033 & 0.923 \\
SBP & -0.362 & 0.275 & $-0.726^{*}$ & 0.011 & 0.483 & 0.132 & 0.238 & 0.482 \\
DBP & $-0.629^{*}$ & 0.038 & -0.403 & 0.219 & 0.547 & 0.081 & 0.218 & 0.561 \\
Hs-CRP & -0.209 & 0.537 & -0.303 & 0.365 & 0.323 & 0.303 & $0.711^{*}$ & 0.014 \\
Cholesterol & 0.462 & 0.152 & 0.403 & 0.219 & 0.427 & 0.190 & -0.248 & 0.462 \\
LDL & 0.072 & 0.834 & 0.260 & 0.441 & -0.050 & 0.885 & 0.443 & 0.173 \\
HDL & -0.182 & 0.593 & 0.022 & 0.948 & 0.021 & 0.950 & -0.347 & 0.296 \\
TG & 0.508 & 0.111 & 0.329 & 0.322 & -0.110 & 0.576 & 0.216 & 0.524 \\
FBG & $0.622^{*}$ & 0.041 & -0.476 & 0.139 & -0.209 & 0.537 & 0.008 & 0.981 \\
F.Insluin & 0.498 & 0.119 & $0.644^{*}$ & 0.002 & -0.290 & 0.387 & 0.249 & $* 0.461$ \\
HOMA-IR & $0.666^{*}$ & 0.025 & 0.485 & 0.130 & -0.257 & 0.445 & 0.315 & 0.346 \\
\hline
\end{tabular}

* Values of Correlation Coefficient are significant at $\mathrm{p}<0.05$.

\section{DISCUSSION}

Chemerin is a pro-inflammatory adipokine which participates in the development of atherosclerosis, aortic stiffness, alteration of insulin sensitivity and glucose uptake. In the present study, there was an evident increase of chemerin in overweight and obese individuals. This result is in agreememt with previous studies (YAMAWAKI, 2011; HOO et al., 2012; NIKLOWITZ et al., 2018; BA et al., 2019). CRP is another pro-inflammatory marker reported by previous studies which showed that there was a direct relation between CRP and BMI (LEHRKE et al., 2009; HAH et al., 2011). This is because of the low-grade inflammation in obesity, that is associated with increase in acute-phase proteins levels (BASTARD et al., 2006). The increase of chemerin, however, is most evident in the hypertensive obese group where the percentage of change reached up to $273 \%$ compared to the normotensive obese group, pointing to the possible role of chemerin in the pathogenesis of hypertension regardless of obesity. Another explanation was provided by high CRP, the pro-inflammatory marker, which experienced a significant increase in obese hypertensive subjects that overwhelms that observed for obesity only. As mentioned earlier, chemerin levels increased in obese subjects in the present study. The significant increase of FI and HOMA-IR in both normotensive obese and hypertensive obese groups pointed to the effect of obesity on insulin sensitivity. Also, the high significant increase of chemerin in hypertensive obese group and the significant increase of HOMAIR in the normotensive obese and hypertensive obese groups pointed to the relation of insulin resistance with obesity and chemerin. LACHINE et al. (2016), reported a significant positive correlation of serum chemerin with HOMA-IR. Also the results obtained by LU et al. (2015) showed that chemerin positively associated with FBG and FI. In addition, the alteration of insulin sensitivity and glucose uptake in adipocytes and skeletal muscle by 
Evaluation of Adipokine...

chemerin may participate in the development of atherosclerosis (BASTARD et al., 2006).

This increase, with the positive correlation between hs-CRP and chemerin in hypertensive group may point to the fact that some sort of inflammation may influence the role of chemerin with hypertension. Some studies confirmed the association of circulating chemerin with hs-CRP and hypertension (ZYLLA et al., 2017; ER et al., 2019). In agreement with the present study, the researchers found that hs-CRP increased in hypertensive patients and its high levels were considered a predictor of hypertension development in prehypertensives and normotensives (SESSO et al., 2003; BAUTISTA et al., 2005).

The pathophysiology of hypertension offer another explanation for the inflammatory nature of hypertension, it includes inflammation which causes arterial stiffness and endothelial dysfunction, insulin resistance, platelet activation and changes causing predisposition to prothrombotic conditions in the coagulation cascade (GILES, 2006).

The high significant increase of chemerin in hypertensive obese pointed to the fact that hypertension and chemerin are closely related to each other. It has been reported that chronic inflammation is a risk factor for arterial hypertension development. In essential hypertension patients, the inflammatory markers such as CRP, TNF- $\alpha$, and IL-6, were shown to be increased (CHAE et al., 2001; SESSO et al., 2003; BAUTISTA et al., 2005). The serum chemerin levels were also correlated with CRP, TNF- $\alpha$, IL-6, resistin, and leptin levels (LEHRKE et al., 2009). The inflammatory cytokines regulate the secretion of chemerin/ CMKLR1 and the expression of CMKLR1 in vascular endothelial cells (KAUR et al., 2010). These studies showed that chemerin contributes in the pathogenesis of hypertension (GU et al., 2014).

Consistent with our study results, GU et al. (2014) and MERIC et al. (2014), reported that plasma chemerin levels were significantly higher in
IBRAHIM, D. R.; TAHA, M. E.; KAMAL, A. M.

the essential hypertensive group compared to the normotensive group. GU et al. (2014) reported a positive correlation between chemerin levels with SBP in hypertensive patients, while LU et al. (2015) reported a significant association between chemerin and DBP. On the other hand, WENG et al. (2017) found that obesity-induced hypertension in male Wistar rats, positively correlated with chemerin in tissues, but not in serum.

There is a close association between hypertension and atherosclerosis. Some studies tried to illustrate the chemerin role in atherosclerosis and cardiovascular diseases (HAH et al., 2011; RHEE, 2011). ZHOU et al. (2019) suggested that chemerin may be a novel prognostic indicator in chronic heart failure. In vitro, chemerin reduces NO production and decreases NO-dependent cGMP signaling so it impaired endothelial dependent vascular relaxation (NEVES et al., 2014). Chemerin also activates adhesion molecules and stimulates endothelial inflammation, as it induces monocyte-endothelial adhesion (YAMAWAKI, 2011; LANDGRAF et al., 2012; DIMITRIADIS et al., 2018). Moreover, chemerin promotes adhesion of macrophages to fibronectin and VCAM-1 by enhancing clustering of the integrins which plays a central role of vascular remodeling (HART; GREAVES, 2010).

\section{CONCLUSION}

From the previous results, it could be concluded that the pro-inflammatory adipokine chemerin increases in obesity and hypertension and is associated with markers of inflammation as hsCRP and predictors of atherosclerosis as LDL. Hence, the serum chemerin level can be used as a reliable indicator of vascular damage in obese individuals. There is a definite dysregulation of the pro-inflammatory and anti-inflammatory parameters towards the pro-inflammatory when the two risk factors, hypertension and obesity are associated.

RESUMO: A chemerin é uma adipocina secretada pelo tecido adiposo e tem papel na obesidade e na hipertensão. Este estudo tem como objetivo avaliar o nível da adipocina chemerina na obesidade e / ou hipertensão e correlacionar seu nível com o marcador inflamatório hs-PCR e os preditores de aterosclerose como perfil lipídico, resistência à insulina, pressão arterial sistólica (PAS) e diastólica (PAD) Os voluntários foram divididos em 4 grupos iguais de acordo com o índice de massa corporal (IMC) e pressão arterial: grupo com peso normal (IMC $\leq 24,9 \mathrm{~kg} / \mathrm{m} 2$ ), grupo com sobrepeso (IMC $=25,0-29,9 \mathrm{~kg} / \mathrm{m} 2$ ), grupo obeso normotenso (IMC $\geq 30,0 \mathrm{~kg} / \mathrm{m} 2$ ) e grupo obeso hipertenso (IMC $\geq 30,0 \mathrm{~kg} / \mathrm{m} 2$ ). Chemerin, proteína Creativa de alta sensibilidade (PCR-as), perfil lipídico, glicemia de jejum (FBG) e insulina de jejum (FI) foram avaliados nos grupos mencionados. Os resultados mostraram que houve aumentos significativos de chemerina, hs- CRP, lipoproteína de baixa densidade (LDL), PAS e PAD no grupo obeso hipertenso em comparação com 
obesos normotensos, com sobrepeso e com peso normal. Além disso, a única correlação positiva significativa entre chemerin e hs-CRP foi observada no grupo de hipertensos obesos. $\mathrm{O}$ grupo obeso normotenso apresentou aumentos significativos de PCR-as, LDL, triglicérides (TG), FBG, FI e o modelo de avaliação da homeostase índice de resistência à insulina (HOMA-IR) comparado aos grupos com sobrepeso e peso normal. Em relação ao grupo com excesso de peso, houve aumento significativo de chemerina, PCR-as, colesterol, LDL, TG em relação ao grupo com peso normal, enquanto os níveis de HDL foram significativamente menores em comparação aos dois grupos obesos. Esses resultados revelaram que a pró-inflamatória adipocina chemerina aumenta na obesidade associada à hipertensão, levando à sugestão de que há uma desregulação definida dos parâmetros pró-inflamatórios e anti-inflamatórios em relação ao pró-inflamatório quando a hipertensão e a obesidade estão associadas.

PALAVRAS-CHAVE: Hipertensão essencial. Citocinas. Pró-inflamação. Obesidade.

\section{REFERENCES}

BA, H. J.; XU, L. L.; QIN, Y. Z.; CHEN, H. S. Serum chemerin levels correlate with determinants of metabolic syndrome in obese children and adolescents. Clin Med Insights Pediatr., v. 5, n. 13, https://doi.org/ 10.1177/1179556519853780

BASTARD, J. P.; MAACHI, M.; LAGATHU, C.; KIM, M. J.; CARON, M.; VIDAL, H.; CAPEAU, J.; FEVE, B. Recent advances in the relationship between obesity, inflammation, and insulin resistance. Eur Cytokine Netw., v. 17, n. 1, p. 4-12, 2006.

BAUTISTA, L. E.; VERA, L. M.; ARENAS, I. A.; GAMARRA, G. Independent association between inflammatory markers (C-reactive protein, interleukin-6, and TNFalpha) and essential hypertension. J Hum Hypertens., v. 19, n. 2, p. 149-154, 2005. https://doi.org/10.1038/sj.jhh.1001785

BOZAOGLU, K.; BOLTON, K.; MCMILLAN, J.; ZIMMET, P.; JOWETT, J.; COLLIER, G.; WALDER, K.; SEGAL, D. Chemerin is a novel adipokine associated with obesity and metabolic syndrome. Endocrinology, v. 148, n. 10, p. 4687-4694, 2007. https://doi.org/10.1210/en.2007-0175

BULLO, M.; CASAS-AGUSTENCH, P.; AMIGO-CORREIG, P.; ARANCETA, J.; SALAS-SALVADO, J. Inflammation, obesity and comorbidities: the role of diet. Public Health Nutrition, v. 10, n. 10A, p. 1164 1172, 2007. https://doi.org/10.1017/S1368980007000663

CHAE, C. U.; LEE, R. T.; RIFAI, N.; RIDKER, P. M. Blood pressure and inflammation in apparently healthy men. Hypertension, v. 38, n. 3, p. 399-403, 2001. https://doi.org/10.1161/01.hyp.38.3.399

CHOBANIAN, A. V.; BAKRIS, G. L.; BLACK, H. R.; CUSHMAN, W. C.; GREEN, L. A.; Izzo, J. L. Jr.; JONES, D. W.; MATERSON; B. J.; OPARIL, S.;WRIGHT, J. T. Jr.; ROCCELLA, E. J. Joint National Committee. The seventh report of the Joint National Committee on detection, evaluation, and treatment of high blood pressure (JNC 7). Hypertension, v. 42, p. 1206-1252, 2003. https://doi.org/10.1001/jama.289.19.2560

DIMITRIADIS, G. K.; KAUR, J.; ADYA, R.; MIRAS, A. D.; MATTU, H. S.; HATTERSLEY, J. G.; KALTSAS, G.; TAN, B. K.; RANDEVA, H. S. Chemerin induces endothelial cell inflammation: activation of nuclear factor-kappa beta and monocyte-endothelial adhesion. Oncotarget, v. 9,n. 24, p. 16678-16690, 2018. https://doi.org/10.18632/oncotarget.24659

ER, L. K.; HSU, L. A.; JUANG, J. J.; CHIANG, F. T.; TENG, M. S.; TZENG, I. S.; WU, S.; LIN, J. F.; KO, Y. L. Circulating Chemerin Levels, but not the RARRES2 Polymorphisms, Predict the Long-Term Outcome of Angiographically Confirmed Coronary Artery Disease. Int J Mol Sci., v. 20, n. 5, pii: E1174, 2019. https://doi.org/10.3390/ijms20051174 
FERNANDEZ-SANCHEZ, A.; MADRIGAL-SANTILLAN, E.; BAUTISTA, M.; ESQUIVEL-SOTO, J.; MORALES-GONZÁLEZ, A.; ESQUIVEL-CHIRINO,C.; DURANTE-MONTIEL, I.; SÁNCHEZRIVERA, G.;VALADEZ-VEGA, C.; MORALES-GONZÁLEZ, J. A. Inflammation, Oxidative Stress, and Obesity. Int J Mol Sci., v. 12, p. 3117-3132, 2011.

GILES, T. D. Assessment of global risk: a foundation for a new, better definition of hypertension. J ClinHypertens., v. 8, p. 5-14, 2006. https://doi.org/10.1111/j.1524-6175.2006.05835.x

GU, P.; JIANG, W.; LU, B.; SHI, Z. Chemerin is associated with inflammatory markers and metabolic syndrome phenotypes in hypertension patients. ClinExpHypertens, v. 36, n. 5, p. 326-332, 2014. https://doi.org/10.3109/10641963.2013.827697

GU, P.; CHENG, M.; HUI, X.; LU, B.; JIANG, W.; SHI, Z. Elevating circulation chemerin level is associated with endothelial dysfunction and early atherosclerotic changes in essential hypertensive patients. $\mathbf{J}$

Hypertens.,v. 33, n. 8, p. 1624-1632, 2015. https://doi.org/ 10.1097/hjh.0000000000000588

HAH, Y. J.; KIM, N. K.; KIM, M. K.; KIM, H. S.; HUR, S. H.;YOON, H. J.; KIM, Y. N.; PARKET, K. G. Relationship between chemerin levels and cardiometabolic parameters and degree of coronary stenosis in Korean patients with coronary artery disease. Diabetes Metab J., v. 35, n. 3, p. 248-254, 2011. https://doi.org/10.4093/dmj.2011.35.3.248

HART, R.; GREAVES, D. R. Chemerin contributes to inflammation by promoting macrophage adhesion to VCAM-1 and fibronectin through clustering of VLA-4 and VLA-5. J Immunol., v. 185, n. 6, p. 3728-3739, 2010. https://doi.org/10.4049/jimmunol.0902154

HOO, H. J.; CHOI, H. Y.; YANG, S. J.; KIM, H.Y.; SEO, J. A.; KIM, S. G.; KIM, N. H.; CHOI, K. M.; CHOI, D. S.; BAIK, S. H. Circulating chemerin level is independently correlated with arterial stiffness. J AtherosclerThromb., v. 19, n. 1, p. 59-68, 2012. https://doi.org/10.5551/jat.9647

JOHN, H.; HIERER, J.; HAAS, O.; FORSSMANN, W. G. Quantification of angiotensin-converting- enzyme mediated degradation of human chemerin $145-154$ in plasma by matrix-assisted laser desorption/ionization-timeof-flight mass spectrometry. Anal Biochem., v. 362, n. 1, p. 117-125, 2007. https://doi.org/10.1016/j.ab.2006.12.001

KANNEL, W. B. Blood pressure as a cardiovascular risk factor: prevention and treatment. JAMA, v. 275, n. 20, p. 1571-1576, 1996. https://doi.org/10.1001/jama.1996.03530440051036

KAUR, J.; ADYA, R.; TAN, B. K.; CHEN, J.; RANDEVA, H. S. Identification of chemerin receptor (ChemR23) in human endothelial cells: chemerin-induced endothelial angiogenesis. BiochemBiophys Res Commun., v. 391, n. 4, p. 1762-1768, 2010. https://doi.org/10.1016/j.bbrc.2009.12.150

LACHINE, N. A.; ELNEKIEDY, A. A.; MEGALLAA, M .H.; KHALIL, G. I.; SADAKA, M. A.; ROHOMA, K. H.; KASSAB, H. S. Serum chemerin and high-sensitivity $C$ reactive protein as markers of subclinical atherosclerosis in Egyptian patients with type 2 diabetes. TherAdvEndocrinolMetab., v. 7, n. 2, p. 47-56, 2016. https://doi.org/10.1177/2042018816637312

LANDGRAF, K.; FRIEBE, D.; ULLRICH, T.; KRATZSCH, J.; DITTRICH, K.; HERBERTH, G.; ADAMS, V.; KIESS, W.; ERBS, S.; KORNER, A. Chemerin as a mediator between obesity and vascular inflammation in children. J ClinEndocrinolMetab., v. 97, n. 4, p. E556-E564, 2012. https://doi.org/10.1210/jc.2011-2937

LEHRKE, M.; BECKER, A.; GREIF, M.; STARK, R.; LAUBENDER, R. P.; ZIEGLER, F.; LEBHERZ, C.; TITTUS, J.; REISER, M.; BECKER, C.; GOKE, B.; LEBER, A. W.; PARHOFER, K. G.; BROEDL, U. C. Chemerin is associated with markers of inflammation and components of the metabolic syndrome but does not predict coronary atherosclerosis. Eur J Endocrinol., v. 161, n. 2,p. 339-344, 2009. https://doi.org/10.1530/eje09-0380 
LU, B.; ZHAO, M.; JIANG, W.; MA, J.; YANG, C.; SHAO, J.; GU, P. Independent association of circulating level of chemerin with functional and early morphological vascular changes in newly diagnosed type 2 diabetic patients. Medicine., v. 94, n. 47, p. e1990, 2015. https://doi.org/10.1097/md.0000000000001990

MAURY, E.; BRICHARD, S. M. Adipokine dysregulation, adipose tissue inflammation and metabolic syndrome. Mol Cell Endocrinol., $\quad$ v. 314, $\quad$ n. 1, p. 1-16, 2010. https://doi.org/10.1016/j.mce.2009.07.031

MERIC, M.; SOYLU, K.; AVCI, B.; YUKSEL, S.; GULEL, O.;YENERCAG, M.; COKSEVIM, M.; Uzun, A. Evaluation of plasma chemerin levels in patients with non-dipper blood pressure patterns. Med SciMonit., v. 20, p. 698-705, 2014. https://doi.org/10.12659/msm.890784

NEVES, K. B.; LOBATO, N. S.; LOPES, R. A.; FILGUEIRA, F. P.; ZANOTTO, C. Z.; OLIVEIRA, A. M.; TOSTES, R. C. Chemerin reduces vascular nitric oxide/cGMP signalling in rat aorta: a link to vascular dysfunction in obesity? ClinSci (Lond)., v. 127, n. 2, p. 111-122, 2014. https://doi.org/10.1042/cs20130286

NIKLOWITZ, P.; ROTHERMEL, J.; LASS, N.; BARTH, A.; REINEHR, T. Link between chemerin, central obesity, and parameters of the metabolic syndrome: findings from a longitudinal study in obese children participating in a lifestyle intervention. International Journal of Obesity, v. 42, p. 1743-1752, 2018.

OUCHI, N.; PARKER, J. L.; LUGUS, J. J.; WALSH, K. Adipokines in inflammation and metabolic disease.Nat Rev Immuol., v. 11, n. 2, p. 85-97, 2011. https://doi.org/10.1038/nri2921

RHEE, E. J. Chemerin: A novel link between inflammation and atherosclerosis? Diabetes Metab J., v. 35, n. 3, p. 216-218, 2011. https://doi.org/10.4093/dmj.2011.35.3.216

RONDINONE, C. M. Adipocyte-derived hormones, cytokines, and mediators. Endocrine, v. 29, n. 1, p. 8190, 2006. https://doi.org/10.1385/endo:29:1:81

ROURKE, J. L.; DRANSE, H. J.; SINAL, C. J. Towards an integrative approach to understanding the role of chemerin in human health and disease. Obes Rev., v. 14, n. 3, p. 245-262,

2013. https://doi.org/10.1111/obr.12009

SESSO, H. D.; BURING, J. E.; RIFAI, N.; BLAKE, G. J.;GAZIANO, J. M.;RIDKER, P. M. C-reactive protein and the risk of developinghypertension. JAMA.,v. 290, p. 2945-2951, 2003.

SHIRAI, K. Obesity as the core of the metabolic syndrome and the management of coronary heart disease.

Curr Med Res Opin., v. 20, n. 3, p. 295-304, 2004. https://doi.org/10.1185/030079903125003008

WANG, Z.; NAKAYAMA, T. Inflammation, a Link between Obesity and Cardiovascular Disease.

Hindawi Publishing Corporation Mediators of Inflammation, p. 1-17, 2010. ID 535918. https://doi.org/10.1155/2010/535918

WATTS, S. W.; DORRANCE, A. M.; PENFOLD, M. E.; ROURKE, J. L.; SINAL, C. J.; SEITZ, B.; SULLIVAN, T. J.; CHARVAt, T. T.; THOMPSON, J. M.; BURNETT, R.; FINK, G. D. Chemerin connects fat to arterial contraction. Arterioscler ThrombVasc Biol., v. 33, n. 6, p. 1320-1328, 2013. https://doi.org/10.1161/atvbaha.113.301476

WENG, C.; SHEN, Z.; LI, X.; JIANG, W.; PENG, L.; YUAN, H.; YANG, K.; WANG, J. Effects of chemerin / CMKLR1 in obesity-induced hypertension and potential mechanism. Am J Transl Res., v. 9, n. 6, p. 30963104, 2017.

YAMAWAKI, H. Vascular effects of novel adipocytokines: focus on vascular contractility and inflammatory responses. Biol Pharm Bull., v. 34, n. 3. p. 307-310, 2011. https://doi.org/10.1248/bpb.34.307 
ZHOU, X.; TAO, Y.; CHEN, Y.; XU, W.; QIAN, Z.; LU, X. Serum chemerin as a novel prognostic indicator in chronic heart failure. J Am Heart Assoc., v.8, n.15, e012091, 2019. https://doi.org/10.1161/jaha.119.012091

ZYLLA, S.; PIETZNER, M.; KUHN, J. P.; VOLZKE, H.; DORR, M.; NAUCK, M.; FRIEDRICH, N. Serum chemerin is associated with inflammatory and metabolic parameters-results of a population-based study.Obesity (Silver Spring), v. 25, n. 2, p. 468-475, 2017. https://doi.org/10.1002/oby.21735 